Article

\title{
Seroprevalence of the Strongyloides stercoralis Infection in Humans from Yungas Rainforest and Gran Chaco Region from Argentina and Bolivia
}

\author{
Rubén O. Cimino ${ }^{1,2, *}$, Pedro Fleitas ${ }^{1,2}$ (D), Mariana Fernández ${ }^{3}$, Adriana Echazú ${ }^{1}$, \\ Marisa Juarez ${ }^{1}$, Noelia Floridia-Yapur ${ }^{1,2,4}$, Pamela Cajal ${ }^{1}$, Alfredo Seijo ${ }^{5,+}{ }^{\text {, }}$, Marcelo Abril ${ }^{6}$, \\ Diego Weinberg ${ }^{6}$, Pablo Piorno ${ }^{3}$, Nicolás Caro ${ }^{1}$, Paola Vargas ${ }^{1}$, José Gil ${ }^{1,7}{ }^{\oplus}$, Favio Crudo ${ }^{3}$ \\ and Alejandro Krolewiecki ${ }^{1}$ (I) \\ 1 Instituto de Investigaciones de Enfermedades Tropicales (IIET-CONICET), Sede Regional Orán, \\ Universidad Nacional de Salta, Orán 4530, Argentina; pedro.fleittas@gmail.com (P.F.); \\ adrianaechazu@hotmail.com (A.E.); marjua_78@hotmail.com (M.J.); narfy89@gmail.com (N.F.-Y.); \\ spcajal@yahoo.com.ar (P.C.); nicolascaro2010@hotmail.com (N.C.); paola.a.vargas.f@gmail.com (P.V.); \\ jgil@conicet.gov.ar (J.G.); alekrol@hotmail.com (A.K.) \\ 2 Cátedra de Química Biológica, Facultad de Ciencias Naturales, Universidad Nacional de \\ Salta, Salta 4400, Argentina \\ 3 Asociación para el desarrollo sanitario regional (ADESAR), San Antonio de Areco, Buenos Aires 2760, \\ Argentina; marianaf411@gmail.com (M.F.); laboratorio@murzicatopiorno.com.ar (P.P.); \\ fgc1937@yahoo.com.ar (F.C.) \\ 4 Instituto de Patología Experimental, Facultad de Ciencias de la Salud (IPE-CONICET), \\ Universidad Nacional de Salta, Salta 4400, Argentina \\ 5 Hospital Muñiz, Buenos Aires, CABA C1282AEN, Argentina; ceijo@intramed.net.ar \\ 6 Fundación Mundo Sano, Buenos Aires, CABA C1061ABC, Argentina; mabril@mundosano.org (M.A.); \\ dweinberg@mundosano.org (D.W.) \\ 7 Instituto de Investigaciones en Energía no Convencional-Sector Salud y Ambiente (INENCO-CONICET), \\ Universidad Nacional de Salta, Salta 4400, Argentina \\ * Correspondence: rubencimino@gmail.com \\ † Deceased in September 2016.
}

Received: 21 April 2020; Accepted: 12 May 2020; Published: 20 May 2020 updates

\begin{abstract}
The threadworm, Strongyloides stercoralis, is endemic in tropical and subtropical areas. Data on the prevalence and distribution of infection with this parasite species is scarce in many critical regions. We conducted a seroprevalence study of $S$. stercoralis infection in 13 locations in the Gran Chaco and Yungas regions of Argentina and Bolivia during the period 2010-2016. A total of 2803 human serum samples were analyzed by ELISA-NIE which has a sensitivity of $75 \%$ and specificity of $95 \%$. Results showed that 551 (19.6\%) of those samples were positive. The adjusted prevalence was $20.9 \%$, (95\% confidence interval (CI) $19.4-22.4 \%)$. The distribution of cases was similar between females and males with an increase of prevalence with age. The prevalence in the different locations ranged from $7.75 \%$ in Pampa del Indio to $44.55 \%$ in Santa Victoria Este in the triple border between Argentina, Bolivia, and Paraguay in the Chaco region. Our results show that $S$. stercoralis is highly prevalent in the Chaco and Yungas regions, which should prompt prospective surveys to confirm our findings and the design and deployment of control measures.
\end{abstract}

Keywords: Strongyloides stercoralis; seroprevalence, epidemiology; Argentina 


\section{Introduction}

Strongyloides stercoralis is a nematode of medical importance widely distributed all over the world affecting several hundred million individuals [1,2]. This threadworm intestinal parasite that infects dogs, cats, and primates including humans is endemic in tropical and subtropical regions with poor sanitation conditions. The infection is frequently asymptomatic and can persist for years without detection [3].

The Gran Chaco is a warm subarid region of 1 million $\mathrm{km}^{2}$ representing the second largest biome in the Americas after the Amazon region, crossed by the Tropic of Capricorn, hosting almost 10 million people in Bolivia, Paraguay, Brazil, and Argentina. With low average population density, it has been identified as a "hot spot" for Neglected Tropical Diseases (NTDs) that requires special emphasis for disease control. Chagas disease and soil-transmitted helminthiasis (STH), including S. stercoralis are the main NTDs with active transmission in the region although burden information is incomplete [4-6]. Subtropical Yungas are distributed in northwestern Argentina and southern Bolivia over approximately $56,000 \mathrm{~km}^{2}$ and represent the austral limit of the wooded system known as the Andean Yungeño forest extending from Venezuela to Argentina. This vegetation type expands across a large altitudinal gradient (400-2300 masl), where tree species turnover promotes the occurrence of three altitudinal belts: (i) pre-montane (400-900 $\mathrm{m}$ asl), (ii) lower forest (900-1600 $\mathrm{m}$ asl), and (iii) upper montane forest (1600-2300 masl) [7].

Argentina is among the countries of Latin America endemic for STH although with varying degrees of prevalence. The areas of high prevalence in Argentina were found in the provinces of Misiones, Chaco, Formosa, and Salta, all of them in the northern of the country [8-10].

S. stercoralis is an exception among soil transmitted helminths of medical importance because it can reproduce within the human host (autoinfection cycle) and allows the infection to perpetuate as a chronic state, which can last for decades. The clinical presentation is varied, and depends on the intensity of the infection and immunological states of the individual. Most patients are asymptomatic, while typical symptoms are abdominal pain, diarrhea, and urticaria [2,3]. The disseminated form of the infection, or hyperinfection syndrome, is most frequently seen in immunosuppressed patients (e.g., transplant recipients, HIV or HTLV-1 infections, corticosteroid use) who experience a life threatening complication triggered by an exponential increase in larvae production and migration to extraintestinal sites [1]. Typically, strongyloidiasis is contracted by the skin penetration of the infective larva (L3) from contaminated soil. The eggs produced by the adult female worm located in the small intestine and the larvae are released in stools. The treatment of choice for strongyloidiasis is ivermectin [2].

To date, most STH prevalence studies are carried out using egg counting methods (Kato-Katz, MiniFLOTAC and McMaster's), whereas techniques like Baermann, Agar plate, and sedimentation/concentration (Telemann) are designed for the detection of larvae of S. stercoralis in stools. However, these techniques are complex and have a relatively low sensitivity [2]. Recent innovations like qPCR, although superior in several reports have not shown significant superior sensitivity in a recent systematic review [11]. Serology has been used in a growing number of surveys appearing as a useful tool for prevalence estimations of S. stercoralis [12-17].

Serological methods are more sensitive and practical than the examination of stools. A variety of commercial kits and in-house tests using either crude or recombinant antigens have been used with different techniques, such as ELISA, IFAT, Luminex, and LIPS for the diagnosis of S. stercoralis infections $[18,19]$. The sensitivity of these serological assays varies from $70 \%$ to $100 \%$, while the specificity is improved when recombinant or purified antigens are used instead of crude antigens [20-23]. The NIE recombinant antigen, a 31-kDa antigen derived from S. stercoralis L3 parasites, represents an alternative for serological diagnosis, with reported sensitivities and specificities of $84-98 \%$ and 95-100\%, respectively, being comparable in performance to the crude antigen-based ELISA [19,23-28]. 
The purpose of this study was to report the seroprevalence of $S$. stercoralis infection in a wide region of the Gran Chaco and Yungas regions in northern Argentina and southern Bolivia using NIE-ELISA, in order to contribute to the understanding of the burden of this infection in the region.

\section{Results}

\subsection{Characteristics of the Populations}

A total of 2803 serum samples from 13 different rural, urban and peri-urban localities distributed through the Gran Chaco and Yungas region from Argentina (12 localities) and Bolivia (one locality) were included in the analysis (Table 1). Of the 2218 samples with demographic information available (excluded Pampa Indio), 42.3\% ( $n=939)$ were male and 57.7\% $(n=1279)$ were female. The age ranged from 1 to 92 years, with a median age $12 \pm$ IQR: 21.25 years old. Among the different age groups, $10.5 \%$ $(n=228)$ were $<5$ years old, $45.9 \%$ between 5 and 15 years old $(n=996)$ age years old, $31.6 \%$ between 15 and 45 years old $(n=686)$, and $11.9 \%(n=259) \geq 45$ years old. 
Table 1. Characteristics of the population studied. masl: meters above sea level.

\begin{tabular}{|c|c|c|c|c|c|c|}
\hline Localities & Department & Province & Country & $\begin{array}{c}\text { Altitude } \\
\text { (masl) }\end{array}$ & Region & Community \\
\hline SRN Orán & \multirow{4}{*}{ Oran $^{(1)}$} & \multirow{10}{*}{ Salta } & & \multirow{3}{*}{$356 \mathrm{~m}$} & Yunga & Periurban \\
\hline Pichanal & & & & & Chaco & Urban \\
\hline Solazuty & & & & & & \multirow{3}{*}{ Rural } \\
\hline Río Blanquito & & & & $773 \mathrm{~m}$ & Yunga & \\
\hline Isla de Cañas & Iruya ${ }^{(1)}$ & & Argentina & $610 \mathrm{~m}$ & & \\
\hline Tartagal & \multirow{2}{*}{ General San Martín (1) } & & & \multirow{2}{*}{$495 \mathrm{~m}$} & Chaco & Periurban-Rural \\
\hline Medialuna & & & & & Yunga & \multirow{2}{*}{ Rural } \\
\hline La Unión & \multirow{3}{*}{ Rivadavia $^{(1)}$} & & & $227 \mathrm{~m}$ & \multirow{3}{*}{ Chaco } & \\
\hline Coronel Juan Solá (Morillo) & & & & $300 \mathrm{~m}$ & & Urban-Rural \\
\hline Santa Victoria Este & & & & $262 \mathrm{~m}$ & & \multirow{4}{*}{ Rural } \\
\hline Pampa del Indio & Libertador Gral San Martin & \multirow{2}{*}{ Chaco } & & $96 \mathrm{~m}$ & \multirow{2}{*}{ Chaco } & \\
\hline Las Leonas & 12 de Octubre & & & $124 \mathrm{~m}$ & & \\
\hline Gutierrez & Cordillera & Santa Cruz & Bolivia & $800 \mathrm{~m}$ & Chaco & \\
\hline
\end{tabular}

(1) Data from Anuario Estadístico 2016-2017. Dirección General de Estadística, provincia de Salta, Argentina. 


\subsection{Seroprevalence Rates}

The overall S. stercoralis seroprevalence was 19.6\% (95\%CI: 18.2-21.1\%) (551/2803) while the adjusted seroprevalence was $20.9 \%$ (95\%CI: 19.4-22.4\%). A wide range of prevalence rates between communities was observed with the lowest (7.75\%) in Pampa del Indio and the highest (44.55\%) in Santa Victoria Este a rural locality at the triple-frontier of Argentina, Bolivia, and Paraguay in the Gran Chaco (Figures 1 and 2). Overall, there was no significant difference in prevalence rates between females and males $(22.4 \%$ and $21.7 \%$, respectively) $(p=0.760)$, with just one locality (SRN Oran) where the difference was significant $(p<0.001)$. The comparison in the prevalence rates between the different age groups with respect to the age group $<5$, showed a significant increase with respect to the age groups $15-44$ and $\geq 45$ years old $(p<0.001)$. No significant difference was observed with the age group $5-14$ years old $(p=0.38)$ (Figure 3 ).

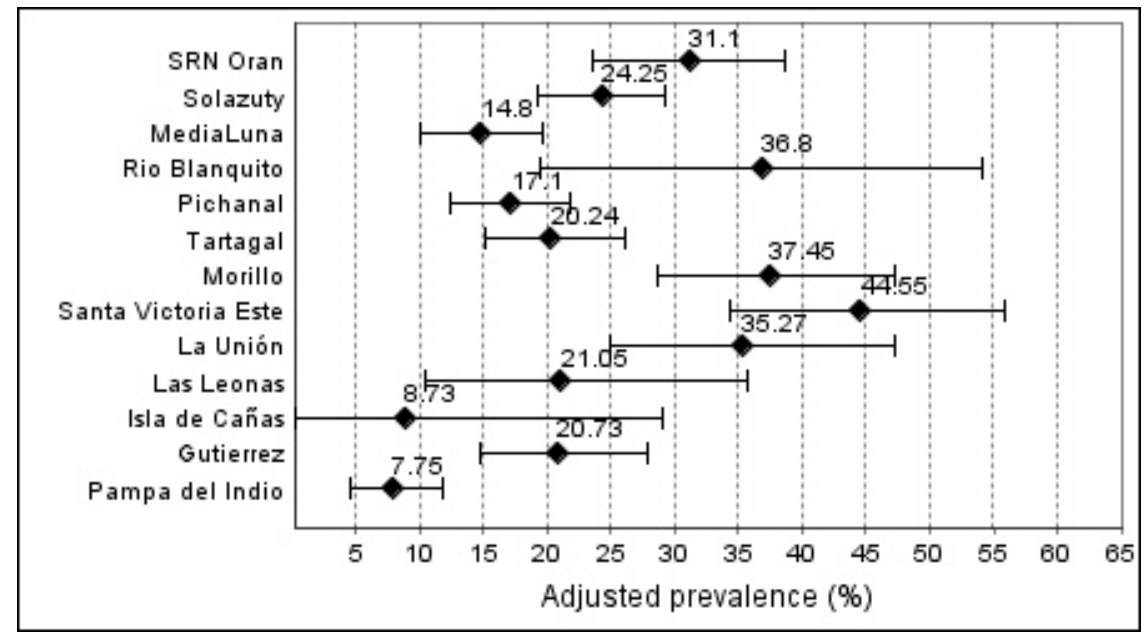

Figure 1. Seroprevalence of the Strongyloides stercoralis infection of localities from Chaco region Argentina-Bolivia.

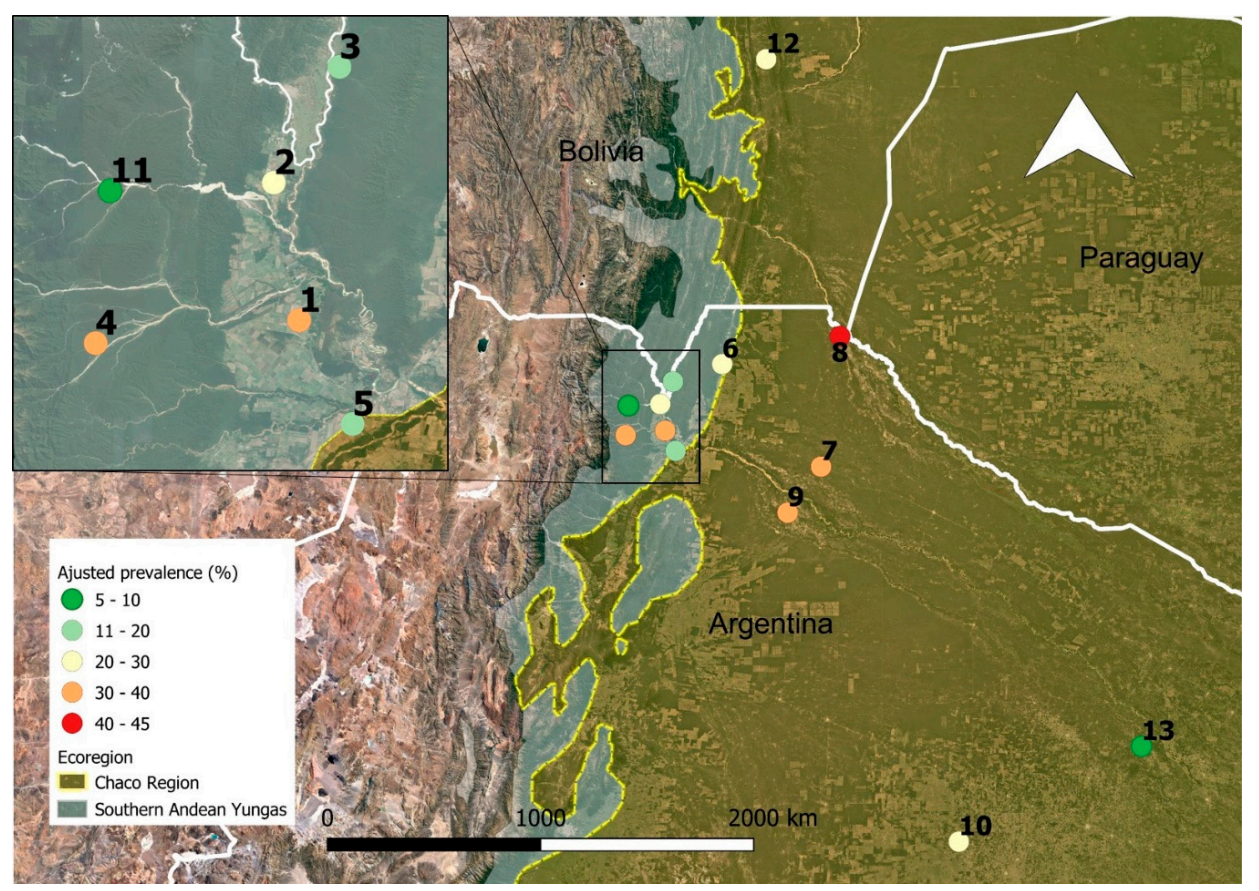

Figure 2. Distribution of seroprevalence by study site and ecoregions. Each number corresponds to a site, 1: SRN Oran; 2: Solazuty; 3: Medialuna; 4: Rio Blanquito; 5: Pichanal; 6: Tartagal; 7: Morillo; 8: Santa Victoria Este; 9: La Unión; 10: Las Leonas; 11: Isla de Cañas; 12: Gutierrez, and 13: Pampa del Indio. 


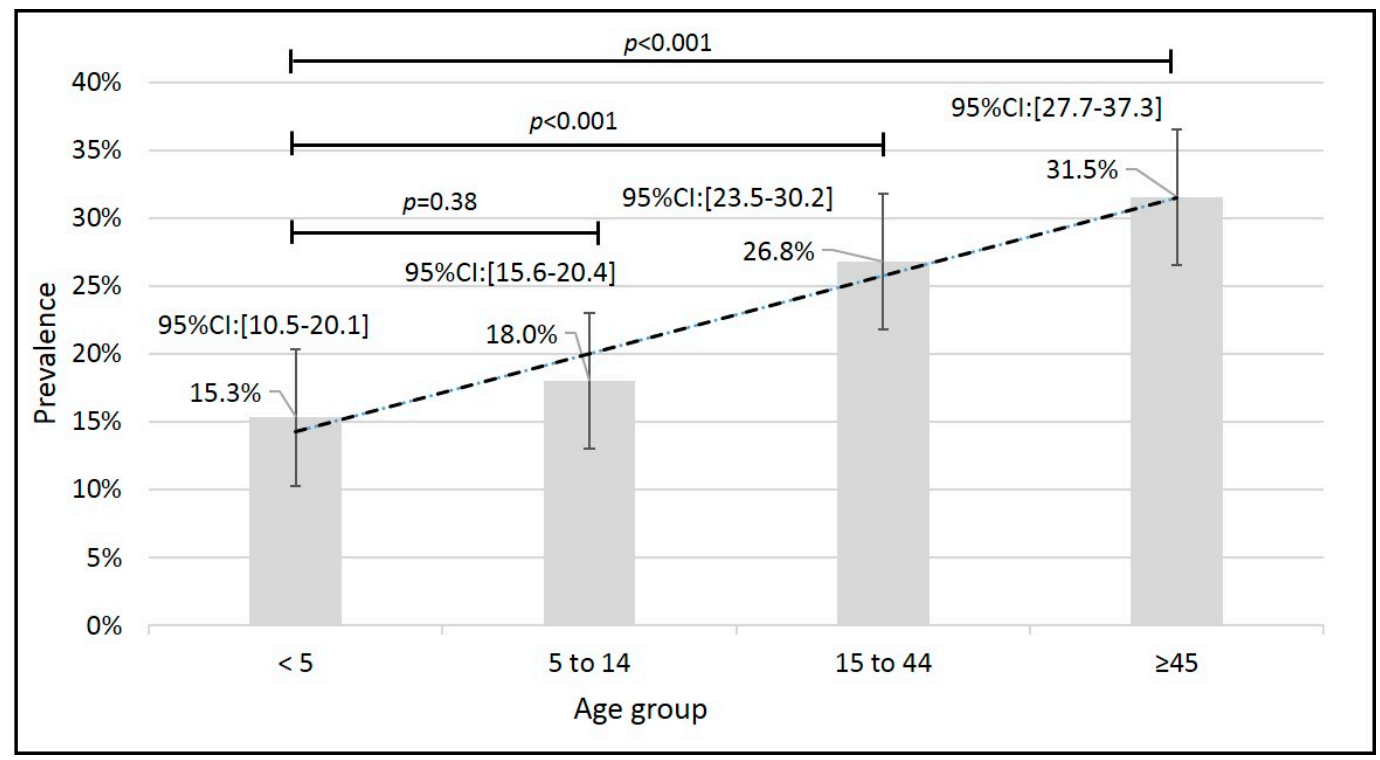

Figure 3. Age-specific prevalence of Strongyloides stercoralis infection by serologic result NIE-ELISA. All age groups were compared to children under five years old (age group $<5$ years).

\section{Discussion}

With over 2000 samples from 13 different communities, this serological survey is the largest report on the current situation of $S$. stercoralis prevalence in the Chaco-Yungas region of the Americas, including communities from diverse localities across the region, highlighting the significant presence of this STH in the population living in this region as well as the need for surveys assessing the burden and distribution of NTDs in the impoverished communities that occupy this area.

Although methods such as Baermann or Agar plate are considered adequate for the diagnosis of $S$. stercoralis infections, their sensitivity is significantly lower than serum antibody detection methods although improved when multiple samples rather than a single stool are analyzed [2,29]. Unfortunately, the use of the Baermann or Agar plate methods is not common in the laboratories of the local health institutions and these methods are rarely used for epidemiological studies. Serological techniques such as ELISA have the advantage that large quantities of samples can be analyzed in a reasonable time and at lower costs [21,30]. Previous reports on the use of the NIE-ELISA technique in epidemiological surveys in an endemic region and in populations where mass drug administration (MDA) campaigns are conducted [13,16,31], have demonstrated the validity and feasibility of this approach that allows the possibility of processing large quantities of samples while also integrating it with other sero-surveillances $[17,23,32]$.

For the current analysis we defined the sensitivity and specificity parameters in $75 \%$ and $95 \%$ based on a blinded comparison between different serological methods and performed the prevalence adjustment based on those parameters [27,33,34].

The results obtained in this study highlight the presence of $S$. stercoralis in the Chaco region and its neighboring Yungas region and confirms previous smaller and more localized reports, which informed prevalence ranging from $<5 \%$ to over $50 \%$ [9,35-38]. Only two localities in our study presented a prevalence $<10 \%$, Isla de Cañas $(8.7 \%)$ and Pampa del Indio $(7.8 \%)$. Systematic reviews on the prevalence of $S$. stercoralis in the region agree on the scarce information and the need for more surveys with adequate design, including standardized, reproducible, and accurate diagnostic methods although still identifying areas with a prevalence $>20 \%[8,9]$

Several recent studies in South America and Asia identified areas with overall prevalence of S. stercoralis infections around $20-25 \%$. This prevalence can increase in rural populations without access to drinking water and sanitary systems [16,39-42]. In Bolivia, a recent study estimated a global seroprevalence of $22 \%$ in Cochabamba Department and 24\% in Santa Cruz Department [34]. In the 
same study, prevalence measured by parasitologic methods averaged $7 \%$, demonstrating that the use of direct methods in epidemiological studies leads to an underestimation of the prevalence of S. stercoralis infection. In our study, the seroprevalence in Gutierrez (Department of Santa Cruz) was 20.7\%, similar to that previously reported in Santa Cruz Department. The population studied corresponds to rural communities, with dirt floors, no electricity, and without improved water and sanitation facilities [34,43]. Our results and conclusions are however somewhat different than those described in a sero-epidemiological study showing a decreasing trend in the prevalence in the Chaco region through a comparison of surveys performed in 1987 (122 samples) in the communities of Camiri and Javillo (both in Santa Cruz Department) and 2013 (233 samples) in Bartolo (Chuquisaca Department) and Ivamirapinta (Santa Cruz Department) [44]. In that report the seroprevalence drops from $16 \%$ to $6 \%$, although geographic differences within the Chaco region, which includes humid rainforest and dry foothills, place limitations in longitudinal comparisons using different communities (Figure 3). Additionally, that study found a higher prevalence at younger ages; in this study we observe that the prevalence increases according to the age group, which coincides with that reported by Steinmann et al. [29] and Schär et al. [45] in rural villages of China and Cambodia, respectively. A similar age distribution was reported in a sero-epidemiological study in the Peruvian Amazon, which calculated that the odd ratios according to age increases between 1 or 2 points per year of age [12].

There is evidence that variables related to personal hygiene such as the presence of a latrine in the home, frequent use of shoes, use of slippers to go to the latrine, and handwashing decrease the risk for S. stercoralis infection [42,46]; in our report it was not possible to make any inference about these behavioral and socioeconomic factors, although in a previous study from our group in communities in the Chaco region of Argentina, there was an association between the lack of adequate sanitation and the presence of infection with hookworms and/or S. stercoralis [14].

A limitation of this study is that we were not able to determine the active infection status at the time of sampling, since the detection of anti-NIE antibodies does not allow to determine if the infection is present or passed, since the drop in antibody titers measured through anti-NIE antibodies can take several months $[13,25]$. There were however, no deworming activities with drugs active against S. stercoralis in the communities included in this study, prior to the surveys $[43,44]$.

\section{Materials and Methods}

\subsection{Study Design}

Different community based serologic surveys on humans were carried out from 2010 until 2016 in different localities of the Gran Chaco and Yungas regions with the goal of evaluating the prevalence and distribution of different NTDs (Tables 1 and 2). Sampled individuals were randomly selected from a population-based census using either individuals or households as the units for randomization (Table 2). These studies were carried out in 12 localities from Argentina from two different provinces (Salta and Chaco) and one from Bolivia (Gutierrez Municipality, Santa Cruz Department) (Figure 2). The surveys were part of a wider project aiming to define strategies for STH control. MDA campaigns with single doses of ivermectin $(200 \mu \mathrm{g} / \mathrm{kg})$ and albendazole $(400 \mathrm{mg})$ free of charge to all participants from the localities (except Las Leonas, Pampa del Indio, and Gutierrez) was offered after the collection of serum samples. 
Table 2. Description of the different studies from which the samples included in this study were obtained.

\begin{tabular}{|c|c|c|c|c|c|c|c|}
\hline Localities & Samples & Year of Study & Basic Sampling Unit & Population & Unimproved Water Supply & Unimproved Sanitation & Cited in \\
\hline SRN Orán & 142 & 2011 & Household & Community & $0 \%$ & $0 \%$ & [14] \\
\hline Pichanal & 489 & 2013 & Household & Community & $0 \%$ & $0 \%$ & [13] \\
\hline Solazuty & 182 & 2010 & Household & Community & $100 \%$ & $100 \%$ & [14] \\
\hline Río Blanquito & 26 & 2010 & Individuals & Community & $100 \%$ & $100 \%$ & None \\
\hline Isla de Cañas & 36 & 2011 & Individual & Community & $100 \%$ & $100 \%$ & None \\
\hline Tartagal & 407 & 2012-2013 & Household & Community & $1 \%$ & $82 \%$ & {$[31]$} \\
\hline Medialuna & 104 & 2016 & Individual & Community & $100 \%$ & $100 \%$ & [27] \\
\hline La Unión & 128 & 2016 & Individual & Community & $6 \%$ & $100 \%$ & None \\
\hline $\begin{array}{l}\text { Coronel Juan Solá } \\
\text { (Morillo) }\end{array}$ & 189 & 2016 & Individual & Community & $86 \%$ & $100 \%$ & None \\
\hline Santa Victoria Este & 152 & 2016 & Individual & Community & $100 \%$ & $100 \%$ & None \\
\hline Pampa del Indio & 585 & 2014 & Individual & Community & $100 \%$ & $100 \%$ & None \\
\hline Las Leonas & 76 & 2008 & Household & Community & $100 \%$ & $100 \%$ & [47] \\
\hline Gutierrez & 287 & 2011-2012 & Household & Community & $100 \%$ & $100 \%$ & [43] \\
\hline
\end{tabular}




\subsection{Serologic Assay}

Seroprevalence was measured using the recombinant antigen NIE from S. stercoralis [24]. The enzyme-linked immunosorbent assay with NIE (NIE-ELISA) was performed as has been previously described with minor modifications [13]. A standard curve was used and values (Unit/mL) interpolated from that standard curve. Cut off was defined using negatives and positives controls sera from stool positive S. stercoralis-infected patients and healthy non-infected individuals. The cut off was set at 120 Units/mL corresponding to sensitivity and specificity of $75 \%$ and $95 \%$, respectively. All blood specimens were centrifuged, and the serum was separated and frozen at $-20{ }^{\circ} \mathrm{C}$ until examination by NIE-ELISA for detection of anti-NIE IgG.

\subsection{Statistical Analyses}

All data (result of serology, age, sex, and location) were organized in Microsoft Excel tables. The adjusted prevalence of $S$. stercoralis infection, including the $95 \%$ confidence intervals $(95 \% \mathrm{CI})$, was calculated using WinEPI: Working in epidemiology (Blas I, 2006; Universidad de Zaragoza, $h t t p: / / w w w . w i n e p i . n e t / m e n u 1 . p h p)$ following formula: $\mathrm{AP}=(\mathrm{OP}+\mathrm{Sp}-1) /(\mathrm{Se}+\mathrm{Sp}-1)$, where AP is the adjusted prevalence, $\mathrm{OP}$ is the observed prevalence of positive serological test result found in our study, and Se (75\%) and Sp (95\%) are the sensitivity and specificity estimates found in the study cited earlier [34]. For the analysis of prevalence according to sex and age, data from Pampa del Indio was excluded because that information was not available.

\subsection{Ethical Considerations}

The study protocol was approved by the Bioethics Committee of the Colegio Médicos de la Provincia de Salta, Argentina ( $\left.\mathrm{N}^{\circ} 14.200\right)$. Sera samples collected in each survey were treated according to the study protocols approved of each particular study. The study was conducted in accordance with principles of the 2013 Declaration of Helsinki. Participation was voluntary and informed consent was obtained from all patients involved in the study.

\section{Conclusions}

Our study confirms the presence of $S$. stercoralis infections at significant prevalence levels in the Chaco-Yungas regions of the Americas, highlighting the need for more in depth surveys within the region in order to understand the diversities within the region and address this and other public health needs of the impoverished communities living in this area. Integration of ivermectin to albendazole or mebendazole in MDA campaigns against STH would add coverage against $S$. stercoralis while also improving efficacy against Trichuris trichiura, therefore providing a tool that along with adequate sanitation and water facilities as well as health education, can aim for the control of STH in the Chaco-Yungas region. This study is also demonstrative of the advantages posed by serological methods in carrying larger scale surveys compared to stool methods that are less accurate, more difficult to standardize and integrate with other activities, and time consuming.

Author Contributions: Conceptualization, R.O.C. and A.K.; Methodology, P.F., M.J., P.C., N.C., P.V., A.E., N.F.-Y., M.F., P.P.; Software, J.G. and R.C.; Validation, A.E., P.F., and R.C., Formal Analysis, R.C. and P.F.; Investigation, A.K. and R.C.; Resources, M.A., D.W., A.S., F.C., A.K. and R.C.; Data Curation, R.C.; Writing-Original Draft Preparation, R.C. and A.K.; Writing-Review and Editing, R.C. and A.K. All authors read and agreed with the final version of this the paper; Visualization, R.C.; Supervision, A.K. and R.C.; Project Administration, A.K.; Funding Acquisition, A.K. and R.C. + A.S. deceased in September 2016. All authors have read and agreed to the published version of the manuscript.

Funding: This work was support by CIUNSa (N²478/19) Universidad Nacional de Salta, and Fundación Mundo Sano, Buenos Aires, Argentina.

Acknowledgments: We are grateful to technical personal and professional from Instituto de Investigaciones de Enfermedades Tropicales (IIET-UNSa), to P. Diosque for providing serum samples from Las Leonas, Chaco province. We also thank Aaron Samuels, Ricardo Bozo, and Tresdiente from Camiri (Bolivia) for providing samples from Gutierrez. 
Conflicts of Interest: The authors declare no conflict of interest.

\section{References}

1. Bisoffi, Z.; Buonfrate, D.; Montresor, A.; Requena-Méndez, A.; Muñoz, J.; Krolewiecki, A.J.; Gotuzzo, E.; Mena, M.A.; Chiodini, P.L.; Anselmi, M.; et al. Strongyloides stercoralis: A Plea for Action. PLoS Negl. Trop. Dis. 2013, 7, e2214. [CrossRef] [PubMed]

2. Krolewiecki, A.; Nutman, T.B. Strongyloidiasis: A Neglected Tropical Disease. Infec. Dis. Clin. North. Am. 2019, 33, 135-151. [CrossRef] [PubMed]

3. Cimino, R.O.; Krolewiecki, A. The Epidemiology of Human Strongyloidiasis. Curr. Trop. Med. Rep. 2014, 1, 216-222. [CrossRef]

4. Hotez, P.J. Ten Global "Hotspots” for the Neglected Tropical Diseases. PLoS Negl. Trop. Dis. 2014, 8, e2496. [CrossRef] [PubMed]

5. Del Fernández, M.; Gaspe, M.S.; Gürtler, R.E. Inequalities in the social determinants of health and Chagas disease transmission risk in indigenous and creole households in the Argentine Chaco. Parasit. vectors 2019, 12, 184. [CrossRef] [PubMed]

6. Porcasi, X.; Catalá, S.S.; Hrellac, H.; Scavuzzo, M.C.; Gorla, D.E. Infestation of Rural Houses by Triatoma Infestans (Hemiptera: Reduviidae) in Southern Area of Gran Chaco in Argentina. J. Med. Entomol. 2006, 43, 1060-1067. [CrossRef]

7. Malizia, L.R.; Pacheco, S.; Blundo, C.M.; Brown, A. Caracterización altitudinal, uso y conservación de las Yungas subtropicales de Argentina. Ecosistemas 2019, 21, 53-73.

8. Socías, M.E.; Fernández, A.; Gil, J.F.; Krolewiecki, A.J. Geohelmintiasis en la Argentina una revisión sistemática. Medicina (B. Aires) 2014, 74, 29-36.

9. Buonfrate, D.; Mena, M.A.; Angheben, A.; Requena-Mendez, A.; Munõz, J.; Gobbi, F.; Albonico, M.; Gotuzzo, E.; Bisoffi, Z. Prevalence of strongyloidiasis in Latin America: A systematic review of the literature. Epidemiol. Infec. 2015, 143, 452-460. [CrossRef]

10. Rivero, M.R.; De Angelo, C.; Nuñez, P.; Salas, M.; Motta, C.E.; Chiaretta, A.; Salomón, O.D.; Liang, S. Environmental and socio-demographic individual, family and neighborhood factors associated with children intestinal parasitoses at Iguazú, in the subtropical northern border of Argentina. PLoS Negl. Trop. Dis. 2017, 11, 1-26. [CrossRef]

11. Buonfrate, D.; Requena-Mendez, A.; Angheben, A.; Cinquini, M.; Cruciani, M.; Fittipaldo, A.; Giorli, G.; Gobbi, F.; Piubelli, C.; Bisoffi, Z. Accuracy of molecular biology techniques for the diagnosis of Strongyloides stercoralis infection-A systematic review and meta-analysis. PLoS Negl. Trop. Dis. 2018, 12, e0006229. [CrossRef] [PubMed]

12. Yori, P.P.; Kosek, M.; Gilman, R.H.; Cordova, J.; Bern, C.; Chavez, C.B.; Olortegui, M.P.; Montalvan, C.; Sanchez, G.M.; Worthen, B.; et al. Seroepidemiology of strongyloidiasis in the Peruvian Amazon. Am. J. Trop. Med. Hyg. 2006, 74, 97-102. [CrossRef] [PubMed]

13. Vargas, P.; Krolewiecki, A.J.; Echazú, A.; Juarez, M.; Cajal, P.; Gil, J.F.; Caro, N.; Nasser, J.; Lammie, P.; Cimino, R.O. Serologic monitoring of public health interventions against Strongyloides stercoralis. Am. J. Trop. Med. Hyg. 2017, 97, 166-172. [CrossRef] [PubMed]

14. Echazú, A.; Bonanno, D.; Juarez, M.; Cajal, S.P.; Heredia, V.; Caropresi, S.; Cimino, R.O.; Caro, N.; Vargas, P.A.; Paredes, G.; et al. Effect of Poor Access to Water and Sanitation As Risk Factors for Soil-Transmitted Helminth Infection: Selectiveness by the Infective Route. PLoS Negl. Trop. Dis. 2015, 9, e0004111. [CrossRef]

15. Forrer, A.; Khieu, V.; Vounatsou, P.; Sithithaworn, P.; Ruantip, S.; Huy, R.; Muth, S.; Odermatt, P. Strongyloides stercoralis: Spatial distribution of a highly prevalent and ubiquitous soil-transmitted helminth in Cambodia. PLoS Negl. Trop. Dis. 2019, 13, e0006943. [CrossRef]

16. Kearns, T.M.; Currie, B.J.; Cheng, A.C.; McCarthy, J.; Carapetis, J.R.; Holt, D.C.; Page, W.; Shield, J.; Gundjirryirr, R.; Mulholland, E.; et al. Strongyloides seroprevalence before and after an ivermectin mass drug administration in a remote Australian Aboriginal community. PLoS Negl. Trop. Dis. 2017, 11, e0005607. [CrossRef]

17. Requena-Méndez, A.; Chiodini, P.; Bisoffi, Z.; Buonfrate, D.; Gotuzzo, E.; Muñoz, J. The Laboratory Diagnosis and Follow Up of Strongyloidiasis: A Systematic Review. PLoS Negl. Trop. Dis. 2013, 7, e2002. [CrossRef] 
18. Ramanathan, R.; Burbelo, P.D.; Groot, S.; Iadarola, M.J.; Neva, F.A.; Nutman, T.B. A luciferase immunoprecipitation systems assay enhances the sensitivity and specificity of diagnosis of Strongyloides stercoralis infection. J. Infect. Dis. 2008, 198, 444-451. [CrossRef]

19. Rascoe, L.N.; Price, C.; Shin, S.H.; McAuliffe, I.; Priest, J.W.; Handali, S. Development of Ss-NIE-1 Recombinant Antigen Based Assays for Immunodiagnosis of Strongyloidiasis. PLoS Negl. Trop. Dis. 2015, 9, e0003694. [CrossRef]

20. Schaffel, R.; Nucci, M.; Carvalho, E.; Braga, M.; Almeida, L.; Portugal, R.; Pulcheri, W. The value of an immunoenzymatic test (enzyme-linked immunosorbent assay) for the diagnosis of strongyloidiasis in patients immunosuppressed by hematologic malignancies. Am. J. Trop. Med. Hyg. 2001, 65, 346-350. [CrossRef]

21. Buonfrate, D.; Formenti, F.; Perandin, F.; Bisoffi, Z. Novel approaches to the diagnosis of Strongyloides stercoralis infection. Clin. Microbiol. Infec. 2015, 21, 543-552. [CrossRef] [PubMed]

22. Van Doorn, H.R.; Koelewijn, R.; Hofwegen, H.; Gilis, H.; Wetsteyn, J.C.F.M.; Wismans, P.J.; Sarfati, C.; Vervoort, T.; Van Gool, T. Use of enzyme-linked immunosorbent assay and dipstick assay for detection of Strongyloides stercoralis infection in humans. J. Clin. Microbiol. 2007, 45, 438-442. [CrossRef] [PubMed]

23. Krolewiecki, A.J.; Ramanathan, R.; Fink, V.; McAuliffe, I.; Cajal, S.P.; Won, K.; Juarez, M.; Di Paolo, A.; Tapia, L.; Acosta, N.; et al. Improved diagnosis of Strongyloides stercoralis using recombinant antigen-based serologies in a community-wide study in northern Argentina. Clin. Vaccine Immunol. 2010, 17, 1624-1630. [CrossRef] [PubMed]

24. Ravi, V.; Ramachandran, S.; Thompson, R.W.; Andersen, J.F.; Neva, F. A Characterization of a recombinant immunodiagnostic antigen (NIE) from Strongyloides stercoralis L3-stage larvae. Mol. Biochem. Parasitol. 2002, 125, 73-81. [CrossRef]

25. Buonfrate, D.; Sequi, M.; Mejia, R.; Cimino, R.O.; Krolewiecki, A.J.; Albonico, M.; Degani, M.; Tais, S.; Angheben, A.; Requena-Mendez, A.; et al. Accuracy of Five Serologic Tests for the Follow up of Strongyloides stercoralis Infection. PLoS Negl. Trop. Dis. 2015, 9. [CrossRef]

26. Anderson, N.W.; Klein, D.M.; Dornink, S.M.; Jespersen, D.J.; Kubofcik, J.; Nutman, T.B.; Merrigan, S.D.; Couturier, M.R.; Theel, E.S. Comparison of three immunoassays for detection of antibodies to Strongyloides stercoralis. Clin. Vaccine Immunol. 2014, 21, 732-736. [CrossRef]

27. Krolewiecki, A.J.; Koukounari, A.; Romano, M.; Caro, N.N.; Scott, A.L.; Fleitas, P.; Cimino, R.; Shiff, C.J. Transrenal DNA-based diagnosis of Strongyloides stercoralis (Grassi, 1879) infection: Bayesian latent class modeling of test accuracy. PLoS Negl. Trop. Dis. 2018, 12, e0006550. [CrossRef]

28. Hafiznur Yunus, M.; Arifin, N.; Balachandra, D.; Anuar, N.S.; Noordin, R. Lateral Flow Dipstick Test for Serodiagnosis of Strongyloidiasis. Am. J. Trop. Med. Hyg. 2019, 101, 432-435. [CrossRef]

29. Steinmann, P.; Zhou, X.-N.; Du, Z.-W.; Jiang, J.-Y.; Wang, L.-B.; Wang, X.-Z.; Li, L.-H.; Marti, H.; Utzinger, J. Occurrence of Strongyloides stercoralis in Yunnan Province, China, and Comparison of Diagnostic Methods. PLoS Negl. Trop. Dis. 2007, 1, e75. [CrossRef]

30. Buonfrate, D.; Perandin, F.; Formenti, F.; Bisoffi, Z. A retrospective study comparing agar plate culture, indirect immunofluorescence and real-time PCR for the diagnosis of Strongyloides stercoralis infection. Parasitology 2017, 144, 812-816. [CrossRef]

31. Echazú, A.; Juarez, M.; Vargas, P.A.; Cajal, S.P.; Cimino, R.O.; Heredia, V.; Caropresi, S.; Paredes, G.; Arias, L.M.; Abril, M.; et al. Albendazole and ivermectin for the control of soil-transmitted helminths in an area with high prevalence of Strongyloides stercoralis and hookworm in northwestern Argentina: A community-based pragmatic study. PLoS Negl. Trop. Dis. 2017, 11. [CrossRef] [PubMed]

32. Lammie, P.J.; Moss, D.M.; Brook Goodhew, E.; Hamlin, K.; Krolewiecki, A.; West, S.K.; Priest, J.W. Development of a new platform for neglected tropical disease surveillance. Int. J. Parasitol. 2012, 42, 797-800. [CrossRef] [PubMed]

33. Bisoffi, Z.; Buonfrate, D.; Sequi, M.; Mejia, R.; Cimino, R.O.; Krolewiecki, A.J.; Albonico, M.; Gobbo, M.; Bonafini, S.; Angheben, A.; et al. Diagnostic accuracy of five serologic tests for Strongyloides stercoralis infection. PLoS Negl. Trop. Dis. 2014, 8, e2640. [CrossRef] [PubMed]

34. Gétaz, L.; Castro, R.; Zamora, P.; Kramer, M.; Gareca, N.; del Torrico-Espinoza, M.; Macias, J.; Lisarazu-Velásquez, S.; Rodriguez, G.; Valencia-Rivero, C.; et al. Epidemiology of Strongyloides stercoralis infection in Bolivian patients at high risk of complications. PLoS Negl. Trop. Dis. 2019, 13, e0007028. [CrossRef] 
35. Taranto, N.J.; Cajal, S.P.; De Marzi, M.C.; Fernández, M.M.; Frank, F.M.; Brú, A.M.; Minvielle, M.C.; Basualdo, J.A.; Malchiodi, E.L. Clinical status and parasitic infection in a Wichí Aboriginal community in Salta, Argentina. Trans. R. Soc. Trop. Med. Hyg. 2003, 97, 554-558. [CrossRef]

36. Menghi, C.I.; Iuvaro, F.R.; Dellacasa, M.A.; Gatta, C.L. Survey of intestinal parasites among an aboriginal community in Salta. Medicina (B. Aires) 2007, 67, 705-708.

37. Cancrini, G.; Bartoloni, A.; Paradisi, F.; Nunez, L.E. Parasitological observations on three Bolivian localities including rural communities, cities and institutions. Ann. Trop. Med. Parasit. 1989, 83, 591-594. [CrossRef]

38. Taranto, N.J.; Bonomi de Filippi, H.; Orione, O. [Prevalence of Strongyloides stercoralis infection in childhood. Orán, Salta, Argentina]. Bol. Chil. Parasitol. 1993, 48, 49-51.

39. Machicado, J.D.; Marcos, L.A.; Tello, R.; Canales, M.; Terashima, A.; Gotuzzo, E. Diagnosis of soil-transmitted helminthiasis in an Amazonic community of Peru using multiple diagnostic techniques. Trans. R. Soc. Trop. Med. Hyg. 2012, 106, 333-339. [CrossRef]

40. Diep, N.T.N.; Thai, P.Q.; Trang, N.N.M.; Jäger, J.; Fox, A.; Horby, P.; Phuong, H.V.M.; Anh, D.D.; Mai, L.T.Q.; Van Doorn, H.R.; et al. Strongyloides stercoralis seroprevalence in Vietnam. Epidemiol. Infec. 2017, 145, 3214-3218. [CrossRef]

41. Forrer, A.; Khieu, V.; Schindler, C.; Schär, F.; Marti, H.; Char, M.C.; Muth, S.; Odermatt, P. Ivermectin Treatment and Sanitation Effectively Reduce Strongyloides stercoralis Infection Risk in Rural Communities in Cambodia. PLoS Negl. Trop. Dis. 2016, 10, e004909. [CrossRef] [PubMed]

42. Khieu, V.; Schär, F.; Marti, H.; Bless, P.J.; Char, M.C.; Muth, S.; Odermatt, P. Prevalence and risk factors of Strongyloides stercoralis in Takeo Province, Cambodia. Parasit. Vectors 2014, 7, 221. [CrossRef] [PubMed]

43. Samuels, A.M.; Clark, E.H.; Galdos-Cardenas, G.; Wiegand, R.E.; Ferrufino, L.; Menacho, S.; Gil, J.; Spicer, J.; Budde, J.; Levy, M.Z.; et al. Epidemiology of and Impact of Insecticide Spraying on Chagas Disease in Communities in the Bolivian Chaco. PLoS Negl. Trop. Dis. 2013, 7. [CrossRef] [PubMed]

44. Spinicci, M.; Macchioni, F.; Mantella, A.; Gabrielli, S.; Roselli, M.; Rojo Mayaregua, D.; Monasterio Pinckert, J.; Gamboa Barahona, H.; Paredes, G.A.; Halkyer, P.; et al. Seroepidemiological trend of strongyloidiasis in the Bolivian Chaco (1987-2013) in the absence of disease-specific control measures. Trop. Med. Int. Health 2017, 22, 1457-1462. [CrossRef] [PubMed]

45. Schär, F.; Inpankaew, T.; Traub, R.J.; Khieu, V.; Dalsgaard, A.; Chimnoi, W.; Chamnan, C.; Sok, D.; Marti, H.; Muth, S.; et al. The prevalence and diversity of intestinal parasitic infections in humans and domestic animals in a rural Cambodian village. Parasitol. Int. 2014, 63, 597-603. [CrossRef] [PubMed]

46. Khieu, V.; Hattendorf, J.; Schär, F.; Marti, H.; Char, M.C.; Muth, S.; Odermatt, P. Strongyloides stercoralis infection and re-infection in a cohort of children in Cambodia. Parasitol. Int. 2014, 63, 708-712. [CrossRef] [PubMed]

47. Monje-Rumi, M.; Brandán, C.P.; Ragone, P.G.; Tomasini, N.; Lauthier, J.J.; Alberti D’Amato, A.M.; Cimino, R.O.; Orellana, V.; Basombrío, M.A.; Diosque, P. Trypanosoma cruzi diversity in the Gran Chaco: Mixed infections and differential host distribution of TcV and TcVI. Infec. Genet. Evol. 2015, 29, 53-59. [CrossRef]

(C) 2020 by the authors. Licensee MDPI, Basel, Switzerland. This article is an open access article distributed under the terms and conditions of the Creative Commons Attribution (CC BY) license (http://creativecommons.org/licenses/by/4.0/). 